\title{
An Empirical Rate Constant Based Model to Study Capacity Fading in Lithium Ion Batteries
}

\author{
Srivatsan Ramesh, ${ }^{1}$ K. Venkata Ratnam, ${ }^{2}$ and Balaji Krishnamurthy ${ }^{1}$ \\ ${ }^{1}$ Department of Chemical Engineering, BITS Pilani, Jawahar Nagar, Hyderabad 500078, India \\ ${ }^{2}$ Department of Mathematics, BITS Pilani, Jawahar Nagar, Hyderabad 500078, India \\ Correspondence should be addressed to Balaji Krishnamurthy; balaji.krishbl@gmail.com
}

Received 26 May 2015; Accepted 15 June 2015

Academic Editor: Sheng S. Zhang

Copyright (c) 2015 Srivatsan Ramesh et al. This is an open access article distributed under the Creative Commons Attribution License, which permits unrestricted use, distribution, and reproduction in any medium, provided the original work is properly cited.

A one-dimensional model based on solvent diffusion and kinetics to study the formation of the SEI (solid electrolyte interphase) layer and its impact on the capacity of a lithium ion battery is developed. The model uses the earlier work on silicon oxidation but studies the kinetic limitations of the SEI growth process. The rate constant of the SEI formation reaction at the anode is seen to play a major role in film formation. The kinetics of the reactions for capacity fading for various battery systems are studied and the rate constants are evaluated. The model is used to fit the capacity fade in different battery systems.

\section{Introduction}

Aging of lithium ion batteries is a major problem for battery manufacturers and manufacturers of electric vehicles. A lifetime of 3000 deep cycles is required for electric vehicle applications. As a result of these expectations, lifetime prediction models are required which help us to estimate the capacity fading in a lithium ion battery. There are several models which are available in literature to study capacity fade in lithium ion batteries. Some of them are empirical and some of them are more physics based.

We will give a brief overview of the phenomenological models available in literature thus far. Darling and Newman [1] have tried to study the performance of a lithium ion battery by modeling the side reactions in a lithium ion battery. Ramasamy et al. [2] developed a mathematical model that predicts the capacity loss of the carbon electrode during open circuit voltage due to continuous reduction of the organic solvent and deintercalation of lithium from the carbon. More recently, Sankarasubramanian and Krishnamurthy [3] have proposed a mathematical model incorporating solvent diffusion and kinetics of side reactions to evaluate the capacity fade in a lithium ion battery. Ploehn et al. [4] have developed a solvent diffusion model to evaluate the capacity fade loss in a lithium ion battery. The authors postulate that capacity fade in a lithium ion battery varies linearly as a square root of time. Safari et al. [5] have developed a mathematical model for capacity fade in a lithium ion battery incorporating solvent decomposition kinetics and solvent diffusion through the SEI layer. Xie et al. [6] have developed a 2-dimensional model integrating the SEI growth model with multiple transport processes. Simulation results indicate that the operating temperature has a great effect on SEI growth and capacity loss. Yan et al. [7] have modeled the SEI growth process as a nucleation phase followed by a SEI growth phase. Christensen and Newman [8] were able to model the SEI growth as a function of the physical properties of the film. However, their simulated film thickness was several orders of magnitude more than the experimental values. Broussely et al. [9] have developed an empirical model to study the capacity fade in lithium ion batteries. Prada et al. [10] have developed a simplified electrochemical and thermal aging model of $\mathrm{LiPEO}_{4}$-graphite lithium ion batteries. Li et al. have developed a capacity fade model for lithium ion batteries based on fuzzy neural network [11]. Abdel Monem et al. have studied the capacity loss in lithium ion batteries as a function of different charging techniques. The authors postulate that the capacity fade in a lithium ion battery depends on the charging methodology used [12]. 
Several experimentalists have studied the capacity fade in lithium ion batteries and its correlation with the formation of the SEI layer. Ratnakumar et al. [13] have carried out detailed experimental studies on the capacity fade mechanisms of lithium ion cells. The authors have evaluated two different types of cells, SAFT DD and Yardney prismatic 7 Ah cells, at various temperatures and SOCs (states of charge). They have evaluated capacity degradation on storage over the course of several hours. Liaw et al. [14] have studied the power fading in cylindrical lithium ion cell (18650). The authors have studied the capacity fade under various conditions of aging and SOC. The authors postulate that the degradation process (as evinced by the formation of the SEI layer) has an activation energy of $55 \mathrm{KJ} / \mathrm{mol}$. Wright et al. [15] have carried out capacity fade studies for two different cell chemistries, a cathode that had a baseline chemistry of $\mathrm{LiNi}_{0.8} \mathrm{Co}_{0.15} \mathrm{Al}_{0.05} \mathrm{O}_{2}$ with binders that were cycle-tested at $25^{\circ} \mathrm{C}$ and $45^{\circ} \mathrm{C}$. They have also studied power losses in a lithium ion battery with a cathode chemistry $\mathrm{LiNi}_{0.8} \mathrm{Co}_{0.1} \mathrm{Al}_{0.1} \mathrm{O}_{2}$ which was cycletested at $25^{\circ} \mathrm{C}$. Belt et al. [16] have tested 6 SAFT America HP$1212 \mathrm{Ah}$ lithium ion cells to evaluate cycle life performance as a power assistant to vehicle battery. The authors postulate that temperature has very little effect on capacity fading for their battery systems. However, several other experimental data and our own model repudiate this observation. Several authors have studied the capacity loss in lithium ion batteries as a function of cathode composition $[17,18]$. Wang and Wan have postulated that the formation of the SEI layer is driven by the electrolyte structure [19]. Most of the experimental data available indicates that the capacity losses in a lithium ion battery are a function of storage time, state of charge, and temperature.

Capacity fade models (based on SEI formation) help battery manufacturers to understand the reasons behind the formation of the SEI layer and its impact on the capacity fading of the battery. This could provide battery manufacturers methods to reduce the capacity fading in lithium ion batteries. Our model has tried to understand the effect of initial solvent concentration and varying solvent concentration at the electrode/SEI layer interphase on the capacity fading in lithium ion batteries. This will enable battery manufacturers to develop ideas to reduce capacity fading in lithium ion batteries.

\section{Model Development}

Our model has built up on the earlier work done by Ploehn et al. [4]. Figure 1 shows the schematic of the formation of the SEI layer in a lithium ion battery. The model makes several assumptions. The film growth is supposed to happen due to the reaction happening at the film/electrode interface. This can be assumed as a moving boundary problem where one of the interfaces is assumed to be constant. The model is assumed to be in Cartesian coordinates.

The battery consists of a negative electrode $\left(\mathrm{Li}_{x} \mathrm{C}_{6}\right)$, a separator, a positive electrode $\left(\mathrm{Li}_{2} \mathrm{Mn}_{2} \mathrm{O}_{4}\right)$, and two current collectors on the electrode ends. The electrolyte solution is $1 \mathrm{M} \mathrm{LiPF} 6$ in a mixture of ethylene carbonate (EC) and dimethyl carbonate (DMC). Literature has indicated to us

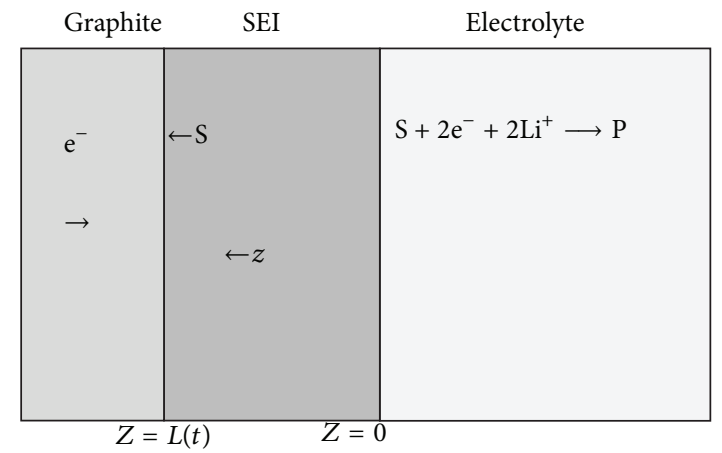

FIGURE 1: Schematic of film growth on the anode surface in a lithium ion battery. The solvent reacts with the lithium at the electrode/film interface to form the lithium carbonate film.

that the majority of the passive film formed is $\mathrm{Li}_{2} \mathrm{CO}_{3}$. According to Christensen and Newman [8], the elementary reactions in the formation of $\mathrm{Li}_{2} \mathrm{CO}_{3}$ can be given by the following.

(1) The adsorption desorption reactions:

$$
\begin{gathered}
\mathrm{Li}^{+}+S \longrightarrow \mathrm{Li}_{s}^{+} \\
\mathrm{EC}+\mathrm{S} \longrightarrow \mathrm{EC}_{s} \\
\mathrm{C}_{2} \mathrm{H}_{4}+2 \mathrm{~S} \longrightarrow \mathrm{C}_{2} \mathrm{H}_{4(s)}
\end{gathered}
$$

The critical film formation reaction is given by

$$
\mathrm{CO}_{3}{ }^{2-}{ }_{(s)}+2 \mathrm{Li}^{+}(s) \longrightarrow \mathrm{Li}_{2} \mathrm{CO}_{3}+3 S
$$

where the subscript $s$ stands for the adsorbed species and $S$ is the available surface site. Though the reactions could be reversible, we are considering the reactions as irreversible in our model. More recently, desolvation of lithium ions has been considered as a rate limiting step by $\mathrm{Xu}$ et al. [20] and Abe et al. [21]. However, we have not focused on this on our model. It is assumed that there is a constant supply of lithium ions at the film/electrode interface and this concentration is unchanging. The growth of the film, the impedance, and the capacity fading in the battery are thus assumed to be solely driven by the solvent concentration at the film electrode interface. Reaction 4 is assumed to be irreversible and the rate constant for the reaction is assumed to be first order. Aurbach $[22,23]$ has postulated that, in addition to $\mathrm{Li}_{2} \mathrm{CO}_{3}$ formation, at high concentration of ethylene carbonate, $\left(\mathrm{CH}_{2} \mathrm{OCO}_{2} \mathrm{Li}\right)_{2}$ can be formed. However, we have not considered this in our model. We have also considered that the SEI layer is a homogenous phase and not a heterogeneous composite phase. The SEI composition and structure varies during storage and cycling and with temperature. However, we have neglected these changes in our model. Ploehn et al.s [4] model assumes that the SEI layer growth and the subsequent capacity fade in a lithium ion battery are solely dependent on diffusion limitations and not kinetic limitations. We have assumed that our model is kinetically limited and diffusion is not a limiting factor in our model. Modeling fit with experimental data proves that the assumption is reasonable. 


\section{Transport Equations and Analytical Solution}

Our transport equations have been developed on similar lines to the model developed by Ploehn et al. [4]. The differential mass balance of the solvent in the SEI phase is given by

$$
\frac{\partial C_{s}}{\partial t}+\frac{\partial N_{z}}{\partial z}=0
$$

Equation (5) is shown to reduce to

$$
N_{z, s}=-D_{s} \frac{\partial C_{s}}{\partial z}
$$

Substitution of (6) into (5) gives

$$
\frac{\partial C_{s}}{\partial t}=D_{s} \frac{\partial^{2} C_{s}}{\partial z^{2}}
$$

The boundary conditions for the equation are given by

$$
\begin{aligned}
& C_{s}=C_{o} \quad \text { at } z=0 \\
& C_{s}=\frac{C_{o}}{e^{k t}} \quad \text { at } z=L(t),
\end{aligned}
$$

where $L(t)$ is the film thickness at any given time. $C_{o}$ is assumed to be the solvent concentration at the film/electrolyte interphase which is a known concentration. Equation (9) is derived from the fact that for a first-order reaction $\ln \left(\left(\ln C_{o}\right) / C_{s}\right)=k t$, where $k$ is the rate constant for the first-order reaction occurring at the film/electrode interphase. Since the film formation reaction happens at the electrode/film interphase this boundary condition is imposed at the interphase. The solution for this has been derived by Slattery [24].

Using the variable $u=z / \sqrt{ } 4 D_{s} t,(7)$ is recast into

$$
\frac{\partial^{2} C_{s}}{\partial u^{2}}+2 u \frac{\partial C_{s}}{\partial u}=0
$$

with the boundary conditions

$$
\begin{aligned}
& \text { At } u=0: C_{s}=C_{o}, \\
& \text { At } u=\lambda: C_{s}=\frac{C_{o}}{e^{k t}},
\end{aligned}
$$

where

$$
\lambda=\frac{L(t)}{\sqrt{ } 4 D_{s} t} .
$$

The solution for (10) with boundary conditions (11) is derived as an offset of the solution by Slattery [24] and is given by the relation

$$
C_{s}(z, t)=C_{o}\left(1+\left(e^{-k t}-1\right) \frac{\operatorname{erf}(u)}{\operatorname{erf}(\lambda)}\right)
$$

Consequently at $z=L(t), u=\lambda$.

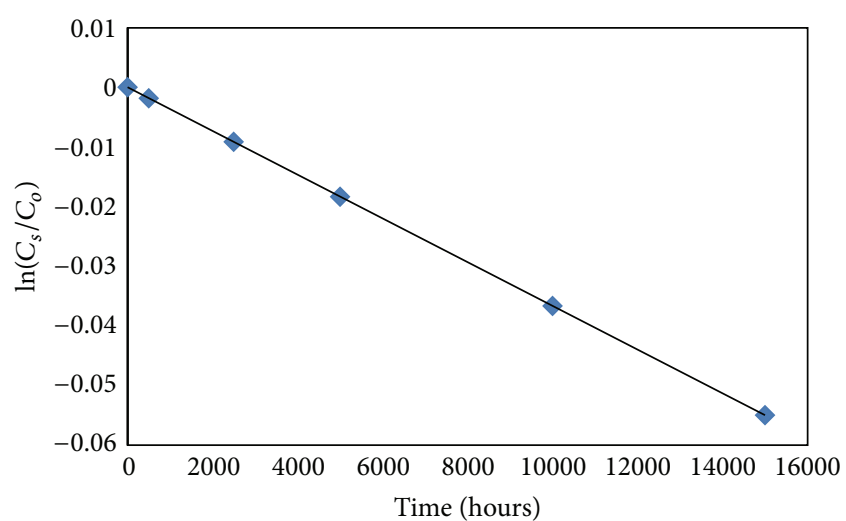

FIGURE 2: Variation of $\ln \left(C_{s} / C_{o}\right)$ as a function of time for a constant rate constant.

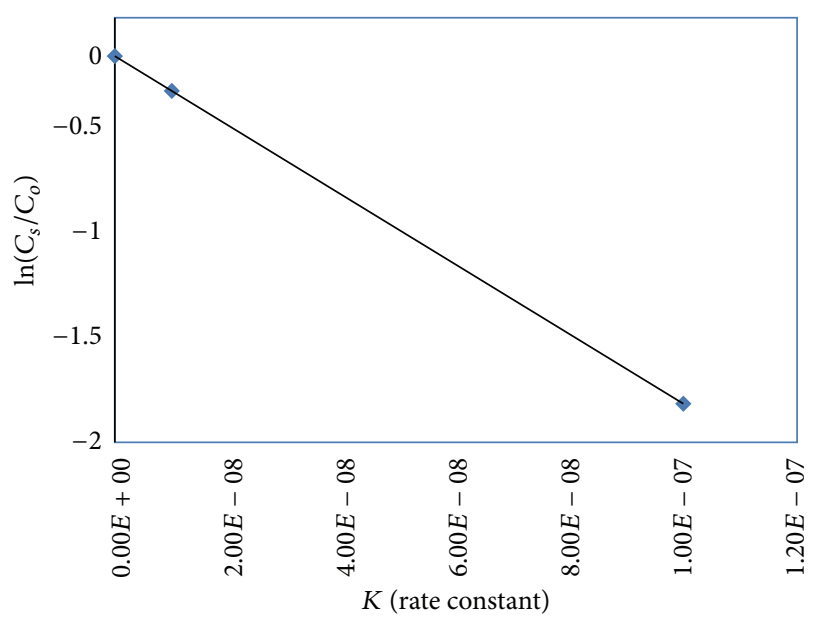

Figure 3: Variation of $\ln \left(C_{s} / C_{o}\right)$ as a function of different rate constants.

The fractional capacity loss for the battery is given by the expression

$$
x(t)=\frac{C_{\mathrm{Lii}}-C_{\mathrm{Lit}}}{C_{\mathrm{Lii}}},
$$

where $C_{\mathrm{Lii}}$ is the initial concentration of lithium available for reaction and $C_{\mathrm{Lit}}$ is the concentration of lithium available at any given time. From (4), it is obvious from the stoichiometry that $2 C_{\mathrm{Li}}=C_{s}$ (the consumption of the solvent species is half of that of lithium). Using this correlation, we can write the fractional capacity loss in a lithium ion battery as $x(t)=\left(C_{o}-\right.$ $\left.C_{s}\right) / C_{o}$.

\section{Results and Discussion}

Figure 2 shows the graphs of $\ln \left(C_{s} / C_{o}\right)$ as a function of time. The graph shows that the concentration of the solvent species keeps decreasing as a function of time for a constant $K$ value $\left(10^{-9} / \mathrm{s}\right)$. Figure 3 shows the graphs of $\ln \left(C_{s} / C_{o}\right)$ as a function of various rate constants ranging from $10^{-7} / \mathrm{s}$ to $10^{-11} / \mathrm{s}$. As it 


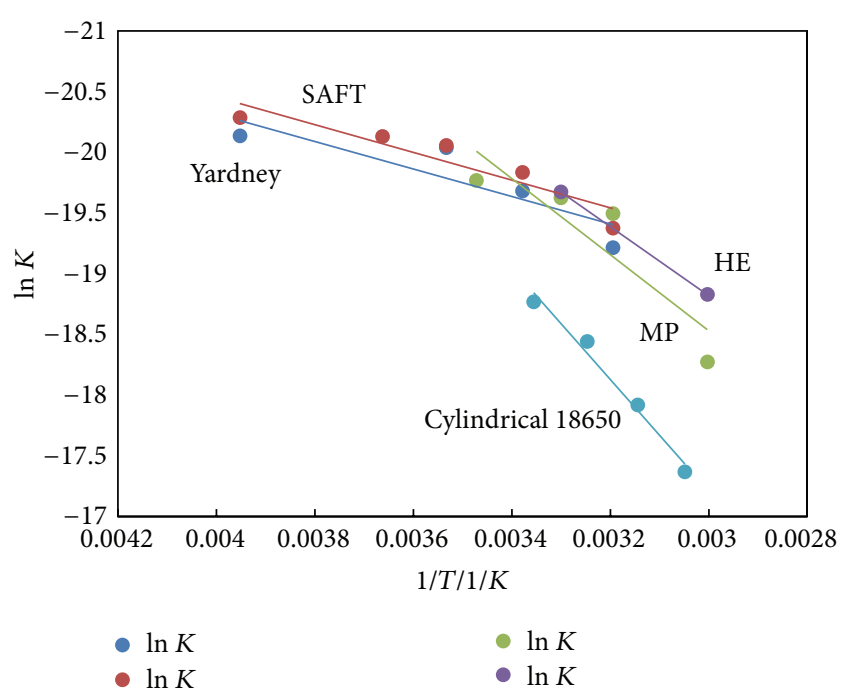

FIGURE 4: Variation of $\ln (K)$ versus $1 / T$ for five different types of cells, Yardney, SAFT, MP, HE, and $18650 \mathrm{Li}$ ion cells from Sandia.

can be seen, the higher the rate constant values, the more the consumption of $C_{s}$ at the film electrode interface.

Figure 4 shows the variation of rate constant values for 4 different types of cells as a function of temperature. The graphs show a linear fit for the graph of $\ln (K)$ versus $1 / T$ obeying Arrhenius expression with a high regression coefficient (though the HE type cell has only 2 data points and we have been able to use only these two data points). The values of the rate constant $K$ have been obtained from the experimental values of capacity fade and fitting it with (13). Table 1 gives a description of the battery systems studied for capacity fade while Table 2 shows the list of parameters used for comparing modeling results with experimental data. Table 3 shows the values of the rate constants obtained for eight different battery systems studied. As can be seen the values of these rate constants vary from $10^{-7} / \mathrm{s}$ to $10^{-9} / \mathrm{s}$ which is consistent with reported data from literature $[5,8,25$, 26]. Several previous models have postulated that the rate constants for forward reactions for typical SEI film formation reaction lie between $10^{-8} / \mathrm{s}$ and $10^{-11} / \mathrm{s}[5,8,25]$. Table 4 shows the energies of activation (for reaction) obtained from the Arrhenius rate expression for 5 different battery systems. It is seen that if the variation of rate constants at different temperatures is not significantly high, then the corresponding activation energy is lower. Thus Yardney [15] and SAFT DD [13] cells are seen to have the lowest reaction activation energy of 9.418 and $9.482 \mathrm{KJ} / \mathrm{mol}$, while the MP type cells [9] and HE type cells [9] are found to have activation energy of $26.05 \mathrm{KJ} / \mathrm{mol}$ and $23.59 \mathrm{KJ} / \mathrm{mol}$. The 18650 cell [14] is found to have the highest reaction activation energy of $38.25 \mathrm{KJ} / \mathrm{mol}$. Unfortunately, most of the data available in literature corresponds to the activation energy of the diffusion process and not the kinetic limitation. Hence, it is very difficult to compare our results with existing data. However, Liaw et al. [14] postulate that for 18650 cells the
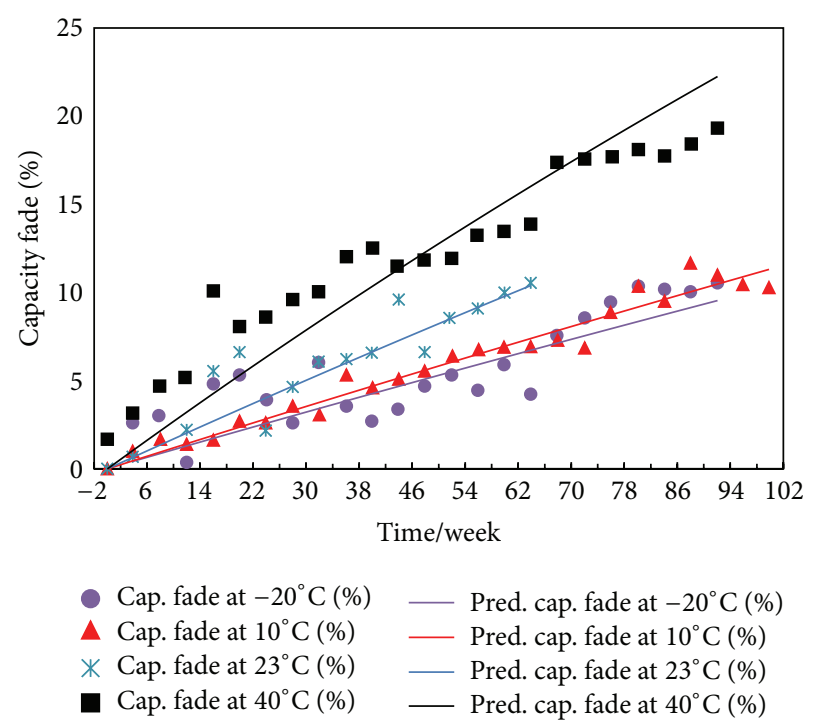

FIGURE 5: Percentage capacity loss versus time for 18650 lithium ion cell (Sandia) at $25^{\circ} \mathrm{C}, 35^{\circ} \mathrm{C}, 45^{\circ} \mathrm{C}$, and $55^{\circ} \mathrm{C}$.

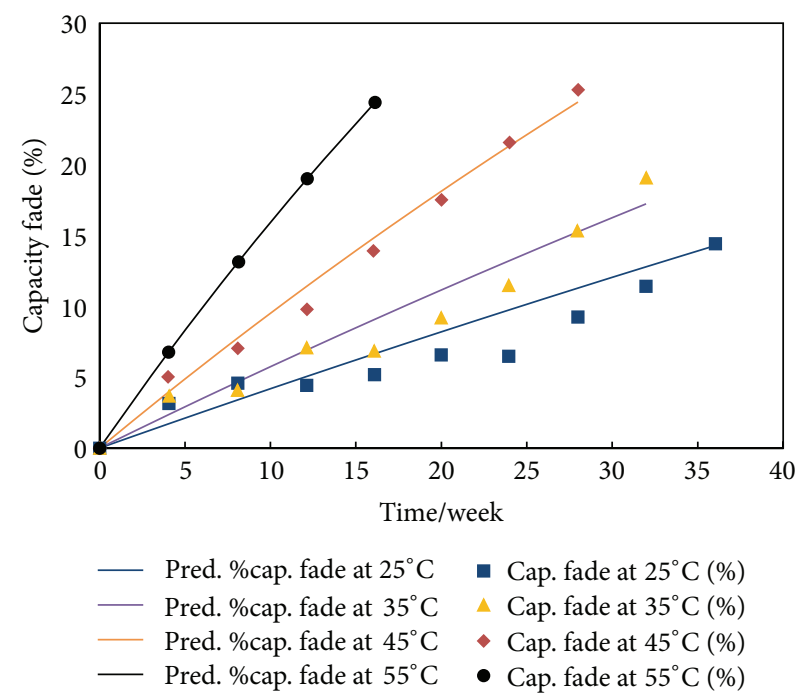

Figure 6: Percentage capacity loss versus time for Yardney cell at $-20^{\circ} \mathrm{C}, 10^{\circ} \mathrm{C}, 23^{\circ} \mathrm{C}$, and $40^{\circ} \mathrm{C}$.

activation energy for the degradation process varies from $35 \mathrm{KJ} / \mathrm{mol}$ to $50 \mathrm{KJ} / \mathrm{mol}$ which approximates our result.

Figure 5 shows the model predictions for capacity fade in a Yardney cell [15] at four different temperatures: $-20^{\circ} \mathrm{C}$, $10^{\circ} \mathrm{C}, 23^{\circ} \mathrm{C}$, and $40^{\circ} \mathrm{C}$. It is seen that model predictions fit very well with experimental data. Figure 6 shows the model predictions for 18650 cells [14] at four different temperatures: $25^{\circ} \mathrm{C}, 35^{\circ} \mathrm{C}, 45^{\circ} \mathrm{C}$, and $55^{\circ} \mathrm{C}$. The model's predictive capabilities are seen to be excellent. As a further test of the model's capacity fade predictions, we have evaluated the model's predictive capabilities with several other experimental data from literature. Figure 7 shows the capacity fade for a SAFT DD cell [11] at five different temperatures: $-20^{\circ} \mathrm{C}, 0^{\circ} \mathrm{C}$, $10^{\circ} \mathrm{C}, 23^{\circ} \mathrm{C}$, and $40^{\circ} \mathrm{C}$. Figure 8 [14] shows the capacity fade 


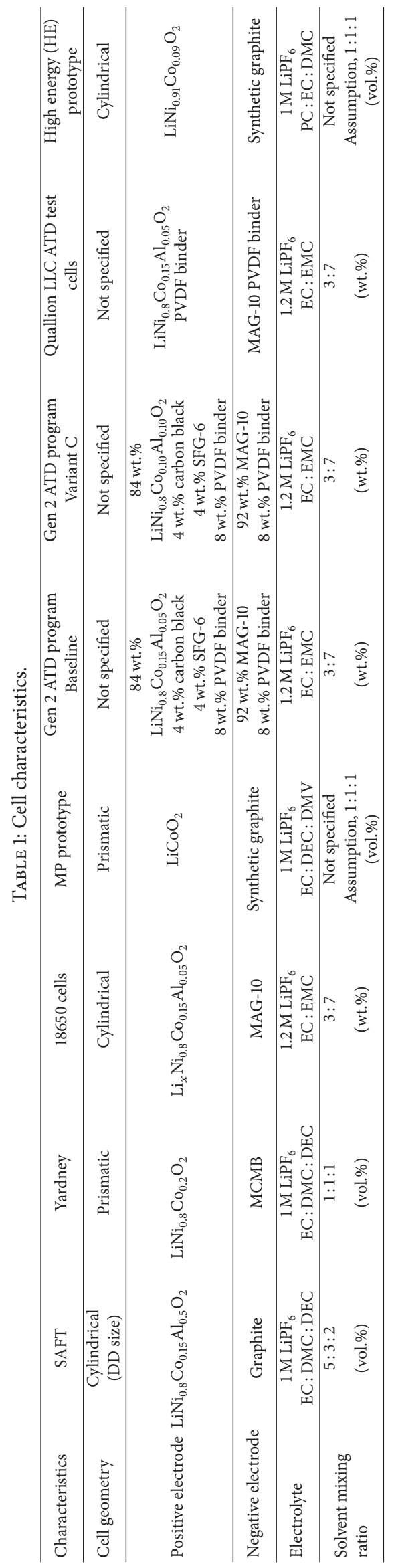


TABLE 2: List of assumed quantities used in the calculations.

\begin{tabular}{lccc}
\hline Assumed quantities & Yardney & $\begin{array}{c}\text { High energy (HE) } \\
\text { prototype }\end{array}$ & MP prototype \\
\hline Rated capacity (Ah) & 7 & 40 & 5 \\
$C_{P}\left(\mathrm{~g} \mathrm{~cm}^{-3}\right)$ & 2.11 & 2.11 & 2.11 \\
$Z_{P}$ & 2 & 2 & 2 \\
$A_{\text {anode }}\left(\mathrm{m}^{2}\right)$ & 30.28 & 173 & 21.5 \\
$N_{0}(\mathrm{~mol})$ & 0.261 & 1.4924 & \\
\hline
\end{tabular}

TABle 3: Dependence of rate constants on temperature. Values of reaction rate constants for different cells.

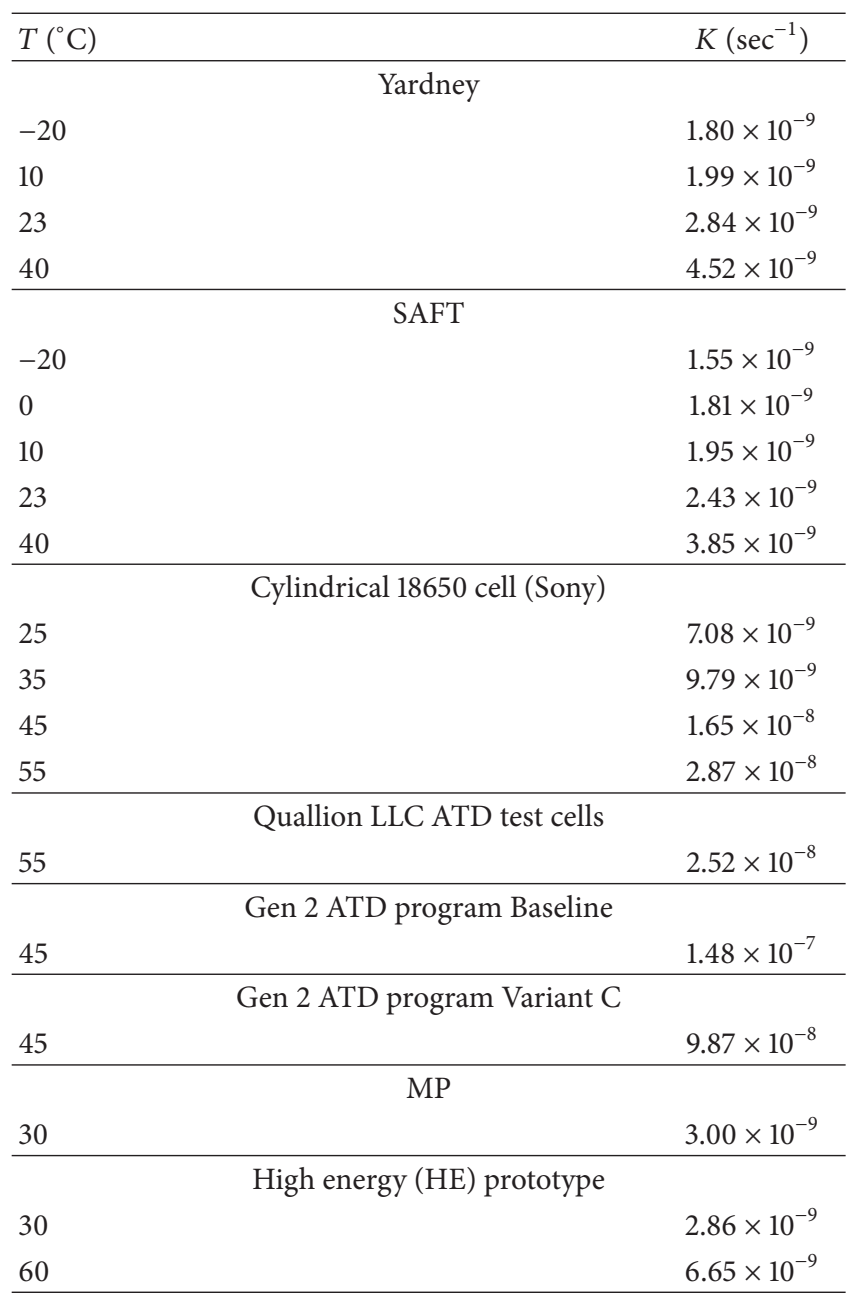

TABLE 4: Reaction activation energies for different battery systems.

\begin{tabular}{lc}
\hline Cell type & $E_{a}\left(\mathrm{~kJ} \mathrm{~mol}^{-1}\right)$ \\
\hline Cylindrical 18650 cell (Sony) & 38.2502 \\
SAFT DD & 9.4829 \\
Yardney & 9.4180 \\
MP & 26.0577 \\
HE & 23.5943 \\
\hline
\end{tabular}

predictions for ATD Gen 2 Baseline cell and Gen 2 Variant C cell at $45^{\circ} \mathrm{C}$ while Figure 9 shows the capacity fade predictions

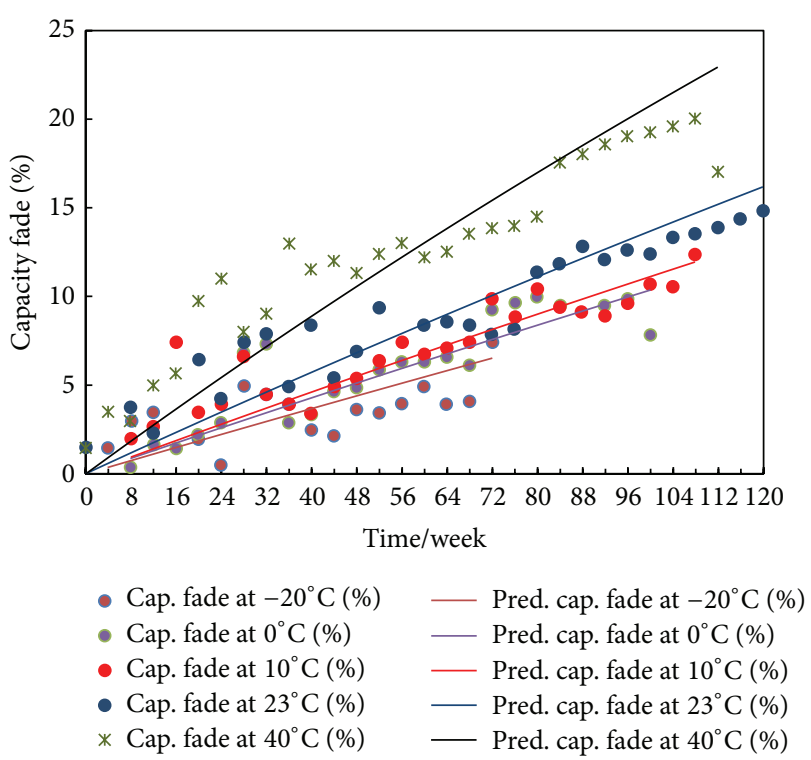

Figure 7: Percentage capacity loss versus time for SAFT cell at $-20^{\circ} \mathrm{C}, 0^{\circ} \mathrm{C}, 10^{\circ} \mathrm{C}, 23^{\circ} \mathrm{C}$, and $40^{\circ} \mathrm{C}$.

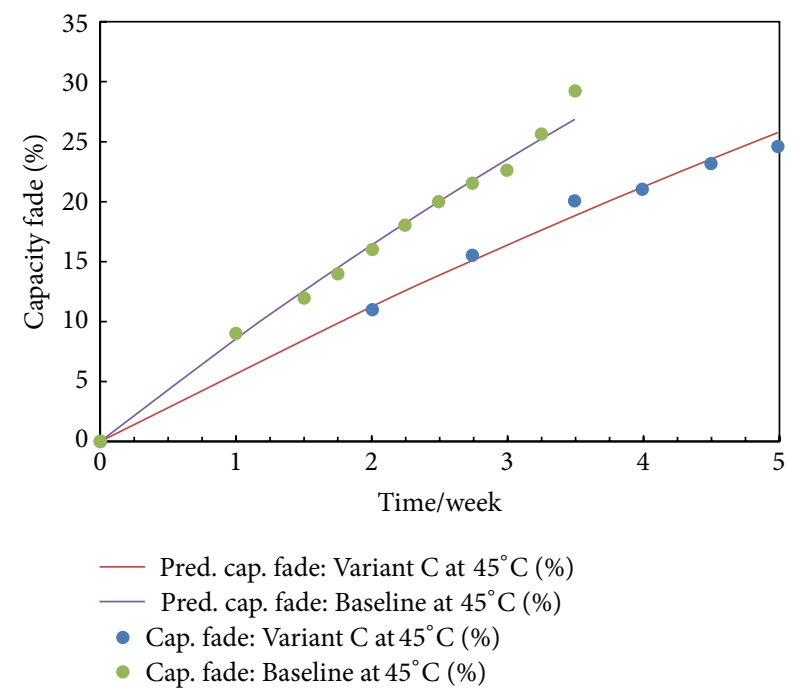

FIgURE 8: Percentage capacity loss versus time for ATD Gen 2 Baseline cell and Gen 2 Variant $\mathrm{C}$ cell at $45^{\circ} \mathrm{C}$.

for Quallion LLC ATD test cell [27] at $55^{\circ} \mathrm{C}$. Modeling predictions are found to have a very good agreement with experimental data in the temperature ranges specified. We have also further studied our model predictions with capacity loss data from HE type and MP type cells from Broussely et al. [9]. Figure 10 shows this modeling fit with experimental data. While the main focus of our model is predicting capacity loss values in lithium ion battery cells, the model can be further extended to study the formation of the SEI layer in the lithium ion battery. Using the capacity fade values at various time intervals predicted by the model, we use the equation for capacity loss obtained by Ploehn et al. [4]

$$
x(t)=\frac{Z_{P} C_{P} A_{\text {Anode }}}{N_{o}} L(t)
$$




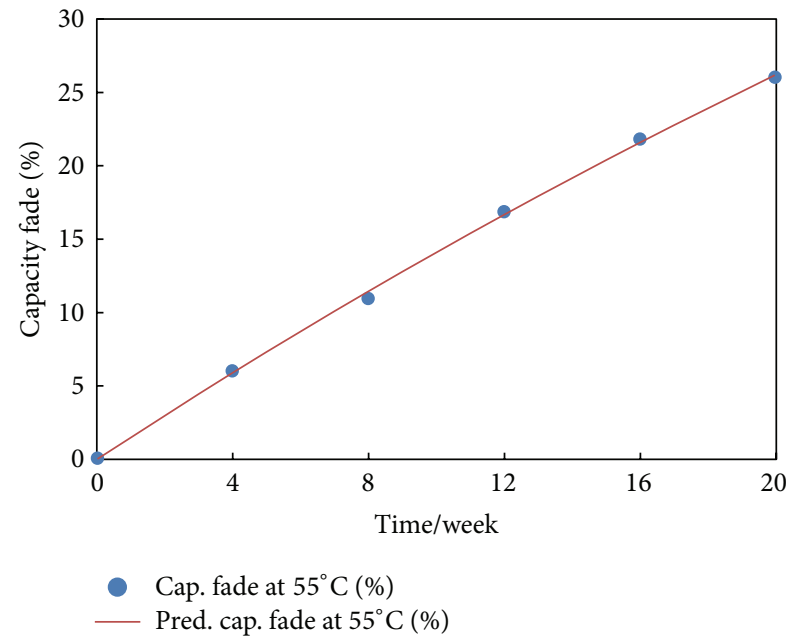

Figure 9: Percentage capacity loss versus time for Quallion LLC ATD test cell at $55^{\circ} \mathrm{C}$.

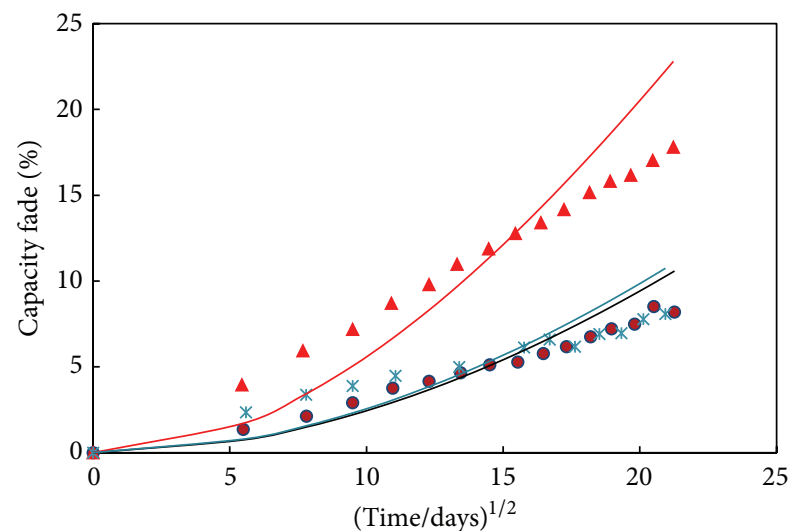
- Cap. fade: $\mathrm{HE}$ cell at $30^{\circ} \mathrm{C}(\%)$
$\triangle$ Cap. fade: $\mathrm{HE}$ cell at $60^{\circ} \mathrm{C}(\%)$
* Cap. fade: MP cell at $30^{\circ} \mathrm{C}(\%)$
- Pred. cap. fade: $\mathrm{HE}$ cell at $30^{\circ} \mathrm{C}(\%)$
- Pred. cap. fade: $\mathrm{HE}$ cell at $60^{\circ} \mathrm{C}(\%)$
— Pred. cap. fade: MP cell at $30^{\circ} \mathrm{C}(\%)$

FIgure 10: Percentage capacity loss versus time for HE type cells (at $30^{\circ} \mathrm{C}$ and $60^{\circ} \mathrm{C}$ ) and $\mathrm{MP}$ type cells (at $30^{\circ} \mathrm{C}$ ).

to predict the film thickness values at various time values. Using our model predictions for MP and HE type cells, we have studied the film thickness values for HE type cells and MP type cells from Broussely et al's [9] data (Figure 11). Model predictions are found to compare well with experimental data. Experimental film thickness values for SEI layer growth are not available for several other battery systems including Yardney cells, SAFT DD cells, and Sandia 18650 cells. Hence, it is not feasible for us to compare the modeling predictions of film growth values to experimental data.

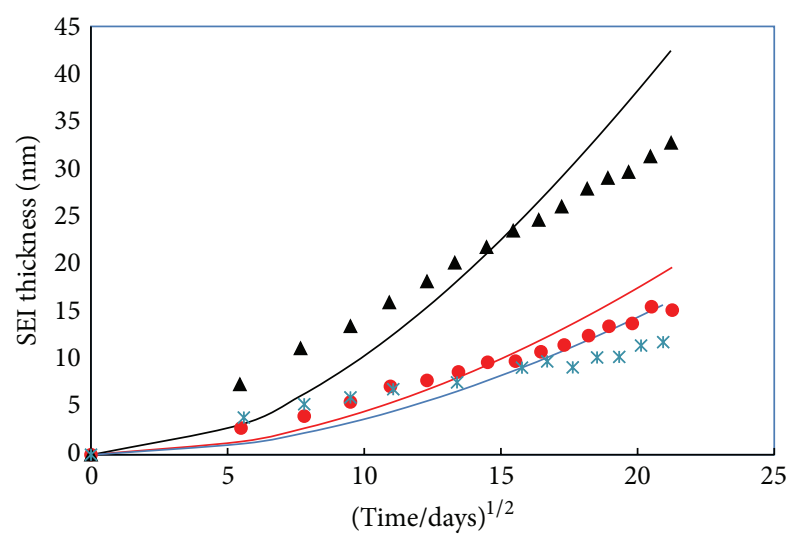

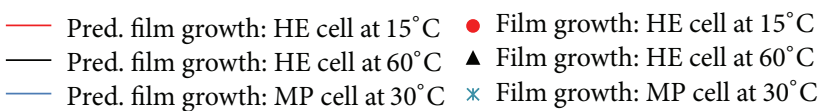

FIGURE 11: Estimated film thickness values from capacity fade model for HE type cell and MP type cell in comparison with experimental data.

\section{Conclusions}

We have presented a first principle, one-dimensional model which is based on kinetic limitations to study the capacity fade in lithium ion batteries. The model assumes that diffusion is not a limiting factor in capacity fade mechanisms in lithium ion batteries. Based on the model which assumes a first-order rate constant, we have evaluated the first-order rate constants for the film formation reaction. The model's predictive capability has been tested with a wide variety of experimental data and is shown to fit the experimental data very well. The model comparison with experimental data indicates to us that, for the wide variety of battery systems considered, kinetics limitations are more important than diffusional limitations. The model can be further used to calculate film thickness values. Thus if one wants to evaluate the capacity loss for a Yardney cell at $60^{\circ} \mathrm{C}$, one has to extract the rate constant at that temperature from our graph and use it to predict the capacity loss at the temperature as a function of time. Further development of the model would involve studying capacity loss as a function of battery chargingdischarging characteristics.

\section{List of Symbols}

$A_{\text {Anode }}$ : Anode area $\left(\mathrm{cm}^{2}\right)$

A: $\quad$ Arrhenius frequency factor

$C_{o}$ : Initial concentration of solvent at

film/electrolyte interface $\left(\mathrm{mol} / \mathrm{cm}^{3}\right)$

$C_{s}: \quad$ Concentration of solvent at time $t$ $\left(\mathrm{mol} / \mathrm{cm}^{3}\right)$

$D_{s}: \quad$ Solvent diffusivity in the SEI phase $\left(\mathrm{cm}^{2} / \mathrm{s}\right)$

$E_{a}$ : Activation energy of the diffusion process, $\mathrm{kcal} / \mathrm{mol}$

$\mathrm{e}^{-}: \quad$ Electron 
K: $\quad$ Rate constant $\left(\mathrm{s}^{-1}\right)$ (for first-order reaction)

$L: \quad$ SEI film thickness $(\mathrm{cm})$

$L(t)$ : SEI film thickness at any time $t(\mathrm{~cm})$

$N_{z}:$ Molar flux $\left(\mathrm{mol} / \mathrm{cm}^{2} \cdot \mathrm{s}\right)$

$N_{z, s}: z$ component of molar flux of component $I, \mathrm{~mol} /\left(\mathrm{cm}^{2} \cdot \mathrm{s}\right)$

$P$ : $\quad$ Product formed as a result of solvent reduction reaction

$R: \quad$ Gas constant, $\mathrm{cal} / \mathrm{mol} \mathrm{K}$

$S: \quad$ Solvent species

$t: \quad$ Time, $s$

T: $\quad$ Temperature, $\mathrm{K}$

$u$ : Similarity transformation variable

$x$ : Fractional capacity loss

$z$ : Coordinate direction normal to the anode $(\mathrm{cm})$

$Z_{P}$ : Stoichiometric coefficient of Li in $P$.

\section{Greek Symbols}

$\lambda$ : A constant in the similarity solution.

\section{Subscripts}

Li: Lithium

$S$ : Solvent

$P$ : Solvent reduction product.

\section{Conflict of Interests}

The authors declare that there is no conflict of interests regarding the publication of this paper.

\section{References}

[1] R. Darling and J. Newman, "Modeling side reactions in composite $\mathrm{Li}_{y} \mathrm{Mn}_{2} \mathrm{O}_{4}$ electrodes," Journal of the Electrochemical Society, vol. 145, no. 3, pp. 990-998, 1998.

[2] R. P. Ramasamy, J. W. Lee, and B. N. Popov, "Simulation of capacity loss in carbon electrode for lithium-ion cells during storage," Journal of Power Sources, vol. 166, no. 1, pp. 266-272, 2007.

[3] S. Sankarasubramanian and B. Krishnamurthy, "A capacity fade model for lithium-ion batteries including diffusion and kinetics," Electrochimica Acta, vol. 70, pp. 248-254, 2012.

[4] H. J. Ploehn, P. Ramadass, and R. E. White, "Solvent diffusion model for aging of lithium-ion battery cells," Journal of the Electrochemical Society, vol. 151, no. 3, pp. A456-A462, 2004.

[5] M. Safari, M. Morcrette, A. Teyssot, and C. Delacourt, "Multimodal physics-based aging model for life prediction of Li-ion batteries," Journal of the Electrochemical Society, vol. 156, no. 3 , pp. A145-A153, 2009.

[6] Y. Xie, J. Li, and C. Yuan, "Multiphysics modeling of lithium ion battery capacity fading process with solid-electrolyte interphase growth by elementary reaction kinetics," Journal of Power Sources, vol. 248, pp. 172-179, 2014.
[7] J. Yan, B.-J. Xia, Y.-C. Su, X.-Z. Zhou, J. Zhang, and X.-G. Zhang, "Phenomenologically modeling the formation and evolution of the solid electrolyte interface on the graphite electrode for lithium-ion batteries," Electrochimica Acta, vol. 53, no. 24, pp. 7069-7078, 2008.

[8] J. Christensen and J. Newman, "A mathematical model for the lithium-ion negative electrode solid electrolyte interphase," Journal of the Electrochemical Society, vol. 151, no. 11, pp. A1977A1988, 2004.

[9] M. Broussely, S. Herreyre, P. Biensan, P. Kasztejna, K. Nechev, and R. J. Staniewicz, "Aging mechanism in Li ion cells and calendar life predictions," Journal of Power Sources, vol. 97-98, pp. 13-21, 2001.

[10] E. Prada, D. di Domenico, Y. Creff, F. Huet, J. Bernard, and V. Sauvant-Moynot, "A simplified electrochemical and thermal aging model of $\mathrm{LiFePO}_{4}$-graphite $\mathrm{Li}$-ion batteries: power and capacity fade simulations," Journal of the Electrochemical Society, vol. 160, no. 4, pp. A616-A628, 2013.

[11] J. Li, F. Tan, C. Zhang, and F. Sun, "Capacity fade diagnosis of lithium ion battery pack in electric vehicles based on fuzzy neural network," Energy Procedia, vol. 61, pp. 2066-2070, 2014.

[12] M. Abdel Monem, K. Trad, N. Omar et al., "Lithium-ion batteries: evaluation study of different charging methodologies based on aging process," Applied Energy, vol. 152, pp. 143-155, 2015.

[13] B. V. Ratnakumar, M. C. Smart, and L. Whitcanack, "Storage characteristics of lithium-ion cells," ECS Transactions, vol. 25, no. 36, pp. 297-306, 2010.

[14] B. Y. Liaw, E. P. Roth, R. G. Jungst, G. Nagasubramanian, H. L. Case, and D. H. Doughty, "Correlation of arrhenius behaviors in power and capacity fades with cell impedance and heat generation in cylindrical lithium-ion cells," Journal of Power Sources, vol. 119, pp. 874-886, 2005.

[15] R. B. Wright, J. P. Christophersen, C. G. Motloch et al., "Power fade and capacity fade resulting from cycle-life testing of advanced technology development program lithium-ion batteries," Journal of Power Sources, vol. 119-121, pp. 865-869, 2003.

[16] J. R. Belt, C. D. Ho, T. J. Miller, M. A. Habib, and T. Q. Duong, "The effect of temperature on capacity and power in cycled lithium ion batteries," Journal of Power Sources, vol. 142, no. 1-2, pp. 354-360, 2005.

[17] S. Watanabe, M. Kinoshita, and K. Nakura, "Capacity fade of $\mathrm{LiNi}_{(1-x-y)} \mathrm{Co}_{x} \mathrm{Al}_{y} \mathrm{O}_{2}$ for lithium-ion batteries during accelerated calendar and cycle life test," Journal of Power Sources, vol. 247, pp. 412-422, 2014.

[18] X. Jin, Q. Xu, H. Liu, X. Yuan, and Y. Xia, "Excellent rate capability of $\mathrm{Mg}$ doped $\mathrm{Li}\left[\mathrm{Li}_{0.2} \mathrm{Ni}_{0.13} \mathrm{Co}_{0.13} \mathrm{Mn}_{0.54}\right] \mathrm{O}_{2}$ cathode material for lithium-ion battery," Electrochimica Acta, vol. 136, pp. 19-26, 2014.

[19] F. M. Wang and C. C. Wan, "Aging effects to SEI membrane formation and the performance analysis of lithium ion batteries," International Journal of Electrochemical Science, vol. 6, p. 1014, 2011.

[20] K. Xu, A. Von Cresce, and U. Lee, "Differentiating contributions to 'ion transfer' barrier from interphasial resistance and $\mathrm{Li}^{+}$ desolvation at electrolyte/graphite interface," Langmuir, vol. 26, no. 13, pp. 11538-11543, 2010.

[21] T. Abe, H. Fukuda, Y. Iriyama, and Z. Ogumi, "Solvated Li-ion transfer at interface between graphite and electrolyte," Journal of the Electrochemical Society, vol. 151, no. 8, pp. A1120-A1123, 2004 . 
[22] D. Aurbach, "Review of selected electrode-solution interactions which determine the performance of $\mathrm{Li}$ and $\mathrm{Li}$ ion batteries," Journal of Power Sources, vol. 89, no. 2, pp. 206-218, 2000.

[23] D. Aurbach, B. Markovsky, I. Weissman, E. Levi, and Y. Ein-Eli, "On the correlation between surface chemistry and performance of graphite negative electrodes for Li ion batteries," Electrochimica Acta, vol. 45, no. 1, pp. 67-86, 1999.

[24] J. C. Slattery, Advanced Transport Phenomena, Cambridge University Press, 1999.

[25] W. Gu, Z. Sun, X. Wei, and H. Dai, "A capacity fading model of lithium-ion battery cycle life based on the kinetics of side reactions for electric vehicle applications," Electrochimica Acta, vol. 133, pp. 107-116, 2014.

[26] A. M. Colclasure, K. A. Smith, and R. J. Kee, "Modeling detailed chemistry and transport for solid-electrolyte-interface (SEI) films in Li-ion batteries," Electrochimica Acta, vol. 58, no. 1, pp. 33-43, 2011.

[27] R. G. Jungst, G. Nagasubramanian, H. L. Case et al., "Accelerated calendar and pulse life analysis of lithium-ion cells," Journal of Power Sources, vol. 119-121, pp. 870-873, 2003. 

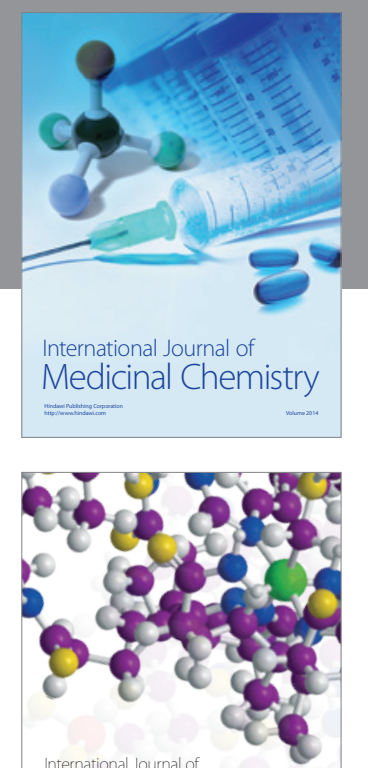

\section{Carbohydrate} Chemistry

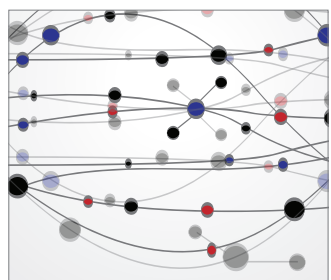

The Scientific World Journal
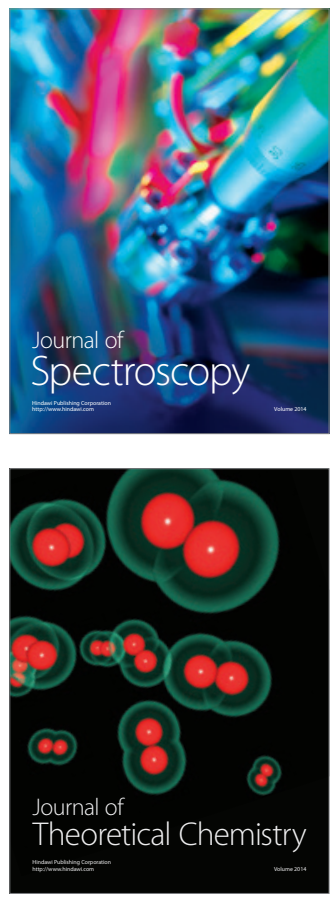
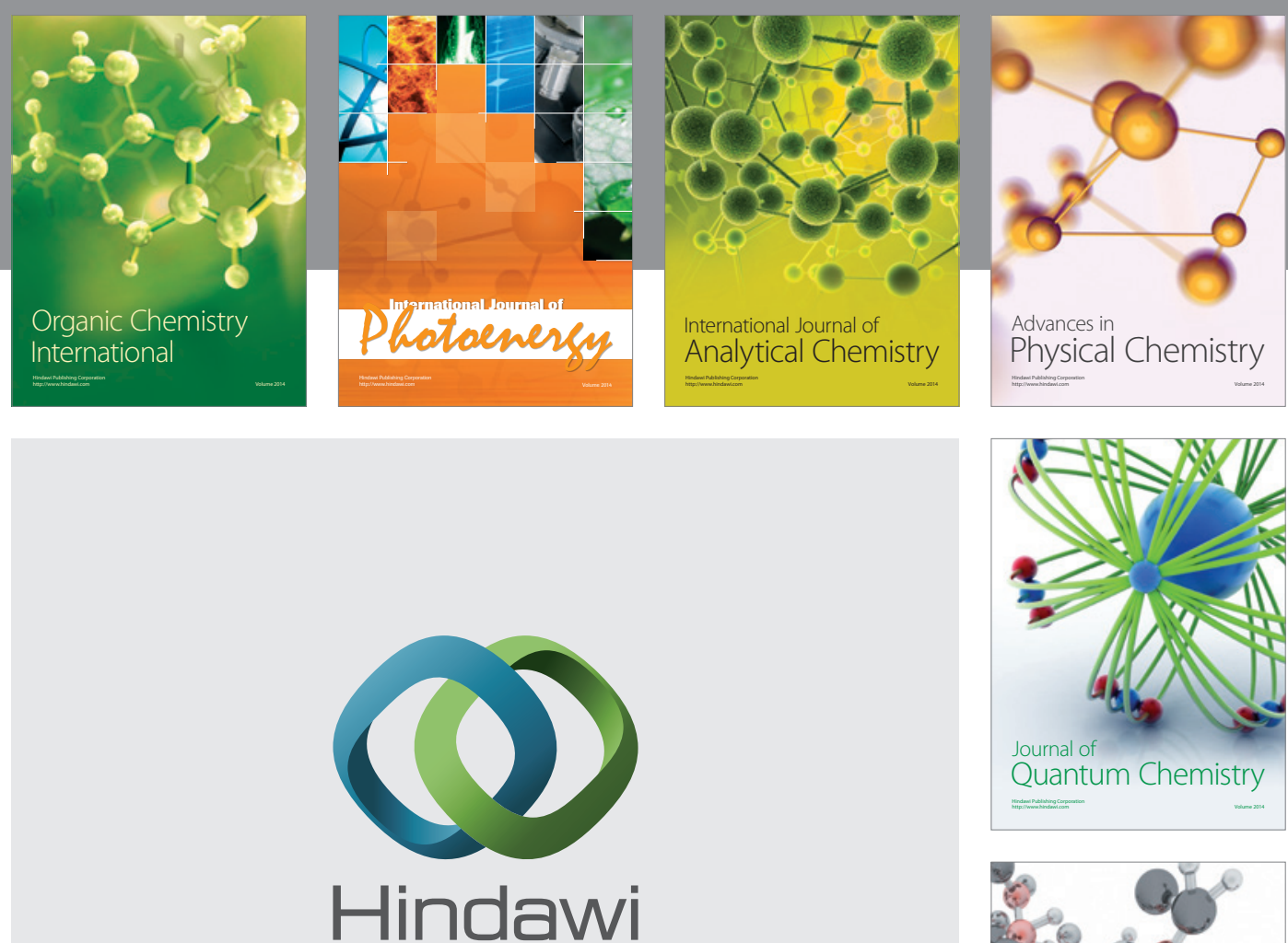

Submit your manuscripts at

http://www.hindawi.com

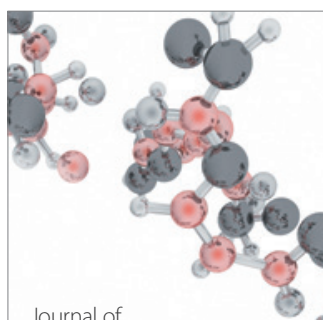

Analytical Methods

in Chemistry

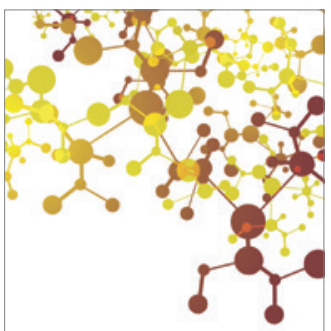

Journal of

Applied Chemistry

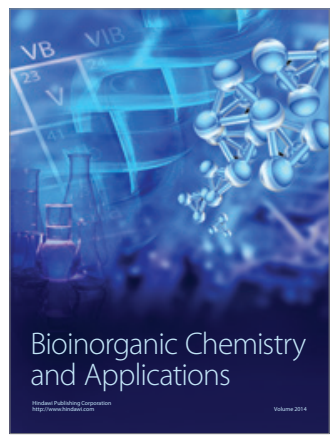

Inorganic Chemistry
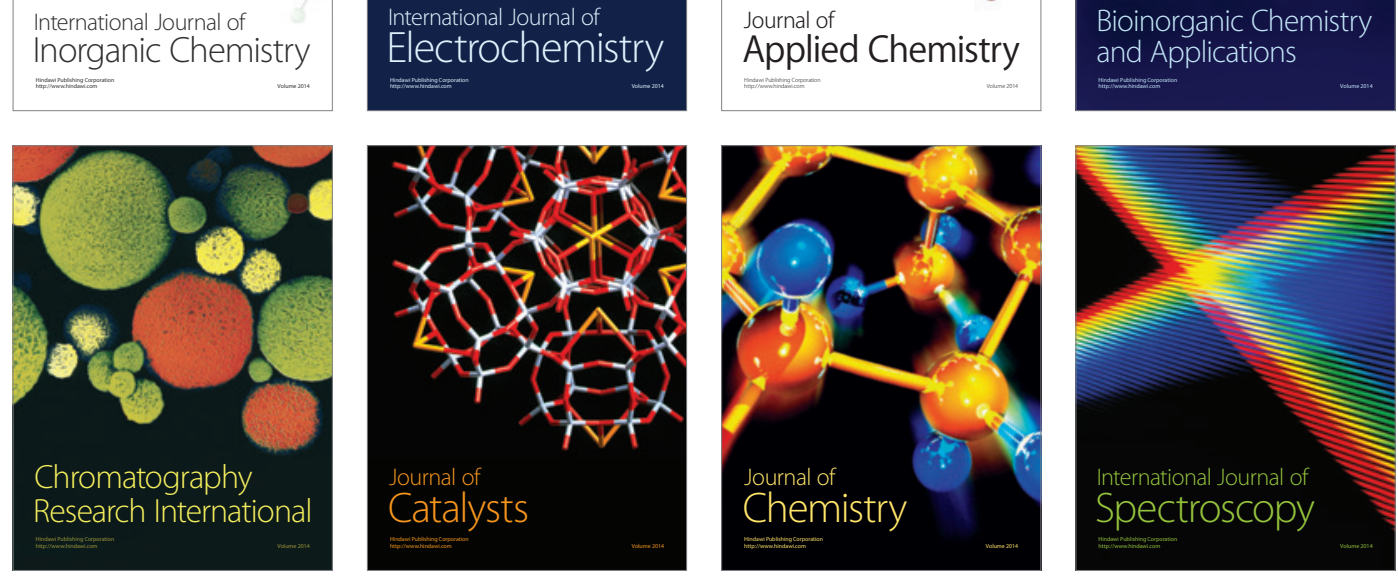